\title{
Energy Conservation and $\mathrm{CO}_{2}$ Abatement Potential of a Gas-injection Blast Furnace
}

https://doi.org/10.1515/htmp-2020-0031

Received Sep 10, 2018; accepted Dec 25, 2018

\begin{abstract}
The gas-injection blast furnace (BF) is a new ironmaking technology with an injecting gas instead of traditional pulverized coal injection (PCI) and recycling of the $\mathrm{BF}$ top gas through a gasifier. In contrast to traditional allcoke and PCI BFs, the coke rate will depend mostly on the heat consumption in a gas-injection $\mathrm{BF}$ with abundant injected gas, which results in a large coke-saving potential. Based on energy conservation, carbon recycling, $\mathrm{CO}_{2}$ abatement and fuel cost, the degree of direct reduction should be between 0.2 and 0.3. In addition, in terms of the effects of the gas injected and the rich oxygen rate in the tuyere region, the optimum injection parameters were obtained, which can reduce the coke rate to $273.36 \mathrm{~kg} / \mathrm{tHM}$, carbon recycling to $100.72 \mathrm{~kg} / \mathrm{tHM}$ and abate carbon dioxide emissions by $94.00 \mathrm{Nm}^{3} / \mathrm{tHM}$. Theoretically, the minimum total carbon consumption value is $399.73 \mathrm{~kg} / \mathrm{tHM}$. These results illustrate the great potential for carbon recycling and coke saving in gas-injection BFs without increasing total carbon consumption.
\end{abstract}

Keywords: gas-injection BF, energy conservation potential, coke-saving potential, $\mathrm{CO}_{2}$ abatement, carbon recycling

\section{Introduction}

The energy-intensive iron and steel industry is responsible for approximately $6.7 \%$ of the total $\mathrm{CO}_{2}$ emissions globally according to the International Energy Agency [1]. The majority of these emissions (over 70\%) are produced by ironmaking blast furnaces (BFs), which also consume the

\footnotetext{
`Corresponding Author: Yana Qie: College of Metallurgy \& Energy, Key Laboratory for Advanced Metallurgy Technology, North China University of Science and Technology, Tangshan 063009, China; Email: 461434073@qq.com

Qing Lyu, Chenchen Lan, Shuhui Zhang: College of Metallurgy \& Energy, Key Laboratory for Advanced Metallurgy Technology, North China University of Science and Technology, Tangshan 063009, China
}

๑ Open Access. ๑ 2020 Y. Qie et al., published by De Gruyter. (cc) BY License largest amount of energy in the entire industry [2]. A traditional BF strongly relies on coke, and the coke rate is responsible for a large part of the production cost. Most of the new trends in blast furnace technology have focused on developing a coke alternative, such as natural gas injection, pulverized coal, waste plastic, biomass, coke oven gas and other hydrocarbon injections [3-10]. However, the practical applicability of these materials strongly depends on the natural resource distribution [11]. In addition, the use of a top gas recycling BF (TGR-BF) has received more interest in recent decades to reach strict energy conservation targets and achieve low $\mathrm{CO}_{2}$ emissions [11, 12]. Top gas recycling and oxygen enrichment in a blast furnace are the primary technologies studied by the ULCOS project [13]. Currently, a number of studies on top gas recycling-oxygen blast furnace (TGR-OBF) have been carried out, including analyses of flow and reducing gas combustion in the tuyeres, $\mathrm{CO}_{2}$ emissions and energy consumption [14-16]. Nonetheless, $\mathrm{CO}_{2}$ capture investments cannot be neglected [17] and add an additional cost of $\$ 56 / \mathrm{tCO}_{2}$ [18]. In addition, too much CO in gas will reduce the gas utilization $[19,20]$. Currently, pulverized coal injection (PCI) is still the main method used to reduce the coke rate [21]. The highest reported PCI amount is approximately $250 \mathrm{~kg} / \mathrm{tHM}$ (ton hot metal), which is similar to the coke amount. However, the impact of coal chemical properties must also be taken because they may prevent its complete combustion within the raceway, affect the gas permeability in the shaft, and contaminate the dead man zone, leading to irregular operation of the furnace and decreasing its productivity [12, 22].

The gas-injection $\mathrm{BF}$ is a new ironmaking technology that injects gas into tuyeres and recycles the BF top gas through a gasifier, which can provide a new gas source and effectively translate the $\mathrm{CO}_{2}$ in the $\mathrm{BF}$ top gas into $\mathrm{CO}$ with a lower cost. In contrast to traditional BF with PCI, gas-injection technology can simplify the ironmaking process and recycle the BF top gas, which can contribute to lower emissions and higher productivities. The technological process is as follows [23, 24]: The BF top gas is injected into the gasifier as the gasifying agent. $\rightarrow$ Coal gasification occurs in the gasifier. $\rightarrow \mathrm{H}_{2}$-rich gas is produced. $\rightarrow \mathrm{H}_{2}$ - 
rich gas is heated in the gas heating device. $\rightarrow$ The hightemperature gas and hot air are injected into the furnace through the tuyere. The technological process is shown in Figure 1.

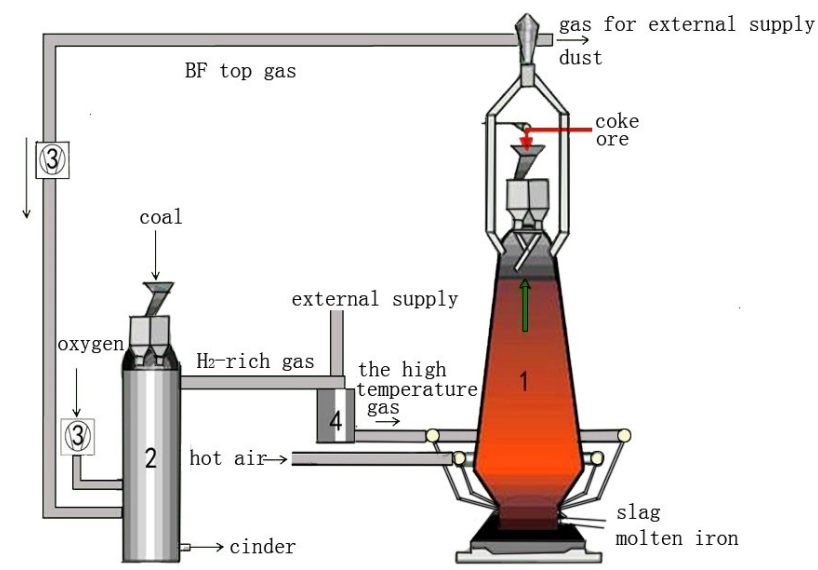

1-blast furnace, 2-gasifier, 3-pressure device, 4-gas heating device

Figure 1: A diagram describing the operation of the gas-injection BF.

In addition, inferior coal with high-volatile and highash contents can be utilized in the gas-making process, which can reduce the amount of high-quality coke in BF smelting $[25,26]$ and increases the hydrogen content in the charging gas to improve the BF production efficiency [27]. In gas-injection $\mathrm{BFs}$, the coke consumption will significantly decrease upon recycling a large amount of the reducing gas.

Many approaches, such as energy and exergy calculations and the conservation supply curve (CSC) and its extended bottom-up model, are current widely used to estimate energy conservation aspects and $\mathrm{CO}_{2}$ emissions reduction in integrated steelworks or specific regions as a result of the implementation of popular technologies [2831]. These estimates show that BF injection technologies, such as pulverized coal and natural gas, have been significant for energy conservation over the last twenty years. The aforementioned methods, however, are not suitable for analyzing the energy-conservation potential of the gasinjection BF due to the current default parameters. Carbon consumption is a crucial energy penalty parameter in BFs. In terms of energy depletion and chemical consumption, the relation between carbon consumption and the direct reduction degree [32], which was established by Professor A.H.Ramm and others, directly reflects the carbon penalty in the $\mathrm{BF}$ and provides a clear direction to decrease carbon consumption. This paper mainly focuses on the energy conservation and $\mathrm{CO}_{2}$ abatement potential of a gas- injection BF using carbon consumption curves. In addition, three scenarios, i.e., a traditional all-coke BF, traditional PCI BF and gas-injection BF, are analyzed, and their energy saving potentials are compared.

\section{Energy conservation and $\mathrm{CO}_{2}$ abatement calculations for gas-injection BFs}

\subsection{Parameter collection}

To predict the carbon consumption characteristics in a gasinjection BF, systems traditionally supplied by only coke ('all-coke') and a traditional BF with PCI were used as comparisons. The conditions for coke, pulverized coal, ironbearing feed and hot metal are shown in Table 1, 2 and 3 based on the conditions used by Tangshan Iron and Steel Enterprises in China.

\subsection{Carbon consumption calculation}

Carbon consumption in the BF ironmaking process can be divided into five aspects [33], including carburization of molten iron $\left(w(\mathrm{C})_{\text {carburization }}\right)$, reduction of microelements $\left(w(C)_{S i, M n, P}\right)$, direct and indirect reduction of iron oxides and energy consumption. The first three carbon consumption mechanisms [32] are the same in all three cases (traditional all-coke BF, traditional PCI BF and gas-injection BF), and the results are shown in Table 4.

For the reduction of ferric oxides, a series of reactions can occur at temperatures greater than $570^{\circ} \mathrm{C}$, i.e., $\mathrm{Fe}_{2} \mathrm{O}_{3} \rightarrow$ $\mathrm{Fe}_{3} \mathrm{O}_{4} \rightarrow \mathrm{FeO} \rightarrow \mathrm{Fe}$ [32]. When a large of gas moves away from the tuyere-raceway region and flow up in $\mathrm{BF}$ shaft, $\mathrm{FeO}$ reduction occurs at first, and then, $\mathrm{Fe}_{3} \mathrm{O}_{4}$ and $\mathrm{Fe}_{2} \mathrm{O}_{3}$ reduction occurs. The reduction of $\mathrm{FeO}$ and $\mathrm{Fe}_{3} \mathrm{O}_{4}$ occurs as the gas in the BF increases, as follows [32]:

$$
\begin{aligned}
& \mathrm{FeO}(\mathrm{s})+\mathrm{nCO}(\mathrm{g})=\mathrm{Fe}(\mathrm{s})+(\mathrm{n}-1) \mathrm{CO}(\mathrm{g})+\mathrm{CO}_{2}(\mathrm{~g}) \\
& \frac{1}{3} \mathrm{Fe}_{3} \mathrm{O}_{4}(\mathrm{~s})+(\mathrm{n}-1) \mathrm{CO}(\mathrm{g})+\mathrm{CO}_{2}(\mathrm{~g})=\mathrm{FeO}(\mathrm{s}) \\
& +\left(\mathrm{n}-\frac{4}{3}\right) \mathrm{CO}(\mathrm{g})+\frac{4}{3} \mathrm{CO}_{2}(\mathrm{~g})
\end{aligned}
$$

The carbon consumption via indirect reduction $\left(w(C)_{i}\right)$ can be obtained as follows.

$$
\begin{aligned}
& w(\mathrm{C})_{\mathrm{i}}=\mathrm{n} \times \frac{12}{56}\left(1-r_{\mathrm{d}}-r_{\mathrm{H}_{2}}\right) \times w(\mathrm{Fe})+\frac{1}{3} \times \frac{12}{56} \times \mathrm{n} \\
& \times \frac{3}{4}\left(r_{\mathrm{d}}+r_{\mathrm{H}_{2}}\right) \times w(\mathrm{Fe})
\end{aligned}
$$


Table 1: Burden system and chemical compositions of iron-bearing feed (mass $\%$ ).

\begin{tabular}{ccccccccccc}
\hline & $\begin{array}{c}\text { Burden } \\
\text { system }\end{array}$ & TFe (total Fe) & $\mathrm{Fe}_{2} \mathrm{O}_{3}$ & $\mathrm{FeO}$ & $\mathrm{CaO}$ & $\mathrm{MgO}$ & $\mathrm{Al}_{2} \mathrm{O}_{3}$ & $\mathrm{SiO}_{2}$ & $\mathrm{~S} / 2$ & others \\
\hline Sinter & 75 & 56.19 & 70.86 & 8.47 & 9.75 & 2.69 & 2.68 & 5.29 & 0.01 & 0.25 \\
Pellet & 15 & 62.82 & 88.42 & 1.20 & 0.81 & 0.43 & 1.44 & 7.50 & 0.01 & 0.19 \\
Lump ore & 10 & 64.51 & 91.39 & 0.69 & 0.08 & 0.90 & 1.47 & 5.30 & 0.00 & 0.17 \\
\hline
\end{tabular}

Table 2: Components of coke and pulverized coal (mass\%).

\begin{tabular}{|c|c|c|c|c|c|c|c|c|c|c|c|c|c|}
\hline & \multirow{2}{*}{$\begin{array}{l}\text { Fixed } \\
\text { carbon }\end{array}$} & \multicolumn{5}{|c|}{ Ash } & \multicolumn{5}{|c|}{ Volatile } & \multirow[t]{2}{*}{$\mathrm{S}$} & \multirow[t]{2}{*}{$\mathrm{H}_{2} \mathrm{O}$} \\
\hline & & $\mathrm{SiO}_{2}$ & $\mathrm{Al}_{2} \mathrm{O}_{3}$ & $\mathrm{CaO}$ & MgO & $\mathrm{FeO}$ & $\mathrm{CO}_{2}$ & $\mathrm{CO}$ & $\mathrm{CH}_{4}$ & $\mathrm{H}_{2}$ & $\mathrm{~N}_{2}$ & & \\
\hline Coke & 86.00 & 6.33 & 4.33 & 0.61 & 0.15 & 1.12 & 0.41 & 0.43 & 0.04 & 0.11 & 0.21 & 0.63 & 3.41 \\
\hline Coal & 74.37 & 4.98 & 2.75 & 0.31 & 0.08 & 0.63 & 1.99 & 1.66 & 1.16 & 3.31 & 8.29 & 0.29 & 1.01 \\
\hline
\end{tabular}

Table 3: Chemical composition of hot metal (mass\%)

\begin{tabular}{cccccc}
\hline Fe & Si & $P$ & $M n$ & $S$ & $C$ \\
\hline 94.59 & 0.43 & 0.11 & 0.51 & 0.03 & 4.34 \\
\hline
\end{tabular}

$$
r_{\mathrm{H}_{2}}=w_{\mathrm{H}_{2}} \eta_{\mathrm{H}_{2}} \times \frac{56}{2} \times \frac{1}{w(\mathrm{Fe})}
$$

where $w(\mathrm{Fe})$ represents the mass of Fe per ton of hot metal, $\mathrm{n}$ is the excess coefficient in the indirect reduction process of iron oxides (the minimum $n$ value is 2.33 [32] in traditional all-coke and PCI BFs.), $r_{d}$ and $r_{H 2}$ indicate the degrees of direct reduction and hydrogen reduction, respectively, and $w\left(\mathrm{H}_{2}\right)$ denotes the mass of $\mathrm{H}_{2}$ in coal and the injected gas. Meanwhile, the $\mathrm{H}_{2}$ utilization $\left(\eta_{\mathrm{H}_{2}}\right)$ is assumed to be $40 \%$, and the hydrogen reduction degree $\left(r_{\mathrm{H} 2}\right)$ is calculated by Eq. (4).

In the gas-injection $\mathrm{BF}$, the amount of the reducing gas is sufficient, and the effect of the excess coefficient on the carbon consumption is not considered in the indirect reduction. In addition, the carbon consumption of the indirect reduction $\left(w(C)_{i 3}\right)$ is the same as that consumed to generate $\mathrm{CO}_{2}\left(w(\mathrm{C})_{\mathrm{CO} 2}\right)$, which is shown as Eq. (5) [34].

$$
\begin{aligned}
& w(\mathrm{C})_{\mathrm{i} 3}=w(\mathrm{C})_{\mathrm{CO}_{2}}=\frac{12}{56} w(\mathrm{Fe})\left(1-r_{\mathrm{d}}-r_{\mathrm{H}_{2}}\right)+\frac{1}{2} \\
& \times \frac{12}{56} w(\mathrm{Fe})
\end{aligned}
$$

Although the gas utilization is differs at different positions in a BF, the CO utilization reaches $45 \%-56 \%$ in the top gas during practical production, and this is expressed by Eq. (6). Meanwhile, the line of $w(\mathrm{C})_{\eta C O=0.5}$ means the carbon consumption when the CO utilization is $50 \%$ during the calculation [35].

$$
\eta_{\mathrm{CO}}=\frac{\phi_{\mathrm{CO}_{2}}}{\phi_{\mathrm{CO}}+\phi_{\mathrm{CO}_{2}}} \times 100 \%=\frac{w(\mathrm{C})_{\mathrm{CO}_{2}}}{w(\mathrm{C})_{\eta \mathrm{CO}}} \times 100 \%
$$

Finally, from an energy consumption perspective, the carbon provided by fuels $(w(C))$ is presented as follows [36].

$$
\begin{aligned}
& w(\mathrm{C})=w(\mathrm{C})_{\text {combustion }}+w(\mathrm{C})_{\mathrm{d}}+w(\mathrm{C})_{\mathrm{Si}, \mathrm{Mn}, \mathrm{P}} \\
& +w(\mathrm{C})_{\text {carburization }}
\end{aligned}
$$

$w(\mathrm{C})_{\text {combustion }}\left(q_{\mathrm{CO}}+q_{\text {blast }}\right)=\sum_{i} Q_{\text {consumption }_{i}}$

$=Q_{\text {reduction }}+Q_{\text {hot metal }}+Q_{\text {slag }}+Q_{\text {top gas }}+Q_{\mathrm{H}_{2} \mathrm{O} \text { evaporation }}$

$+Q_{\text {loss }}+Q_{\text {coal decomposition }}$

$Q_{\text {reduction }}=\sum_{i} Q_{\text {reduction, } \mathrm{i}}=Q_{\text {direct reduction }}$

$+Q_{\text {indirect reduction }}+Q_{\mathrm{Si}, \mathrm{Mn}, \mathrm{P} \text { reduction }}=\frac{152190}{56} w(\mathrm{Fe}) \times r_{\mathrm{d}}$

$+\frac{47522}{2 \times 72} w_{\text {silicate }}+\frac{1549}{160} w_{\mathrm{Fe}_{2} \mathrm{O}_{3}}+\frac{20883}{232} w_{\mathrm{Fe}_{3} \mathrm{O}_{4}}$

$+\frac{27718}{56} w(\mathrm{Fe}) \times r_{\mathrm{H}_{2}}-\left(\frac{13605}{56}\right) w(\mathrm{Fe})\left(1-r_{\mathrm{d}}-r_{\mathrm{H}_{2}}\right)+5087$

$\times w(\mathrm{Mn})+22049 \times w(\mathrm{Si})+15490 \times w(\mathrm{P})$

$Q_{\text {top gas }}=Q_{\mathrm{CO}_{2} \text {, top gas }}+Q_{\mathrm{CO} \text {,top gas }}+Q_{\mathrm{N}_{2} \text {,top gas }}$

$+Q_{\mathrm{H}_{2} \text {, top gas }}+Q_{\mathrm{H}_{2} \mathrm{O} \text {, top gas }}=\frac{11847}{12} w(\mathrm{C})_{\mathrm{CO}_{2}}$

$+\frac{8229}{12}\left(w(\mathrm{C})_{\mathrm{d}}+w(\mathrm{C})_{\text {combustion }}-w(\mathrm{C})_{\mathrm{CO}_{2}}\right)+\frac{8202}{22.4}$

$\times 0.79 V_{\text {blast }}+\frac{7974}{2} w_{\mathrm{H}_{2}} \eta_{\mathrm{H}_{2}}+\frac{7044}{2} \times w_{\mathrm{H}_{2}}\left(1-\eta_{\mathrm{H}_{2}}\right)$

$V_{\text {blast }}=\frac{w(\mathrm{C})_{\text {combustion }}}{24} \times 22.4 \times \frac{0.21}{\frac{f}{0.79-f}+0.21}$ 
Table 4: Carbon consumption for each processing segment

\begin{tabular}{|c|c|}
\hline Items & Carbon consumption $/ \mathrm{kg} \cdot(\mathrm{tHM})^{-1}$ \\
\hline Molten iron carburization & $w(\mathrm{C})_{\text {carburization }}=43.4$ \\
\hline Reduction of minor elements & $\begin{array}{c}w(\mathrm{C})_{S i, M n, P}=12 / 28^{\star} 2^{\star} \mathrm{w}[\mathrm{Si}]+12 / 55^{\star} \mathrm{w}[\mathrm{Mn}]+60 / 62^{\star} \mathrm{w}[\mathrm{P}]= \\
5.83\end{array}$ \\
\hline Direct reduction & $w(\mathrm{C})_{d}=12 / 56^{\star} \mathrm{w}[\mathrm{Fe}]^{\star} r_{d}=202.69 r_{d}$ \\
\hline $\begin{array}{l}\text { Indirect reduction in traditional all-coke and } \mathrm{PCl} \\
\qquad \mathrm{BFs}\end{array}$ & $w(\mathrm{C})_{i}=472.27-354.21 r_{d}-354.21 r_{H 2}=445.87-354.21 r_{d}$ \\
\hline Indirect reduction in a gas-injection BF & $\begin{array}{c}w(\mathrm{C})_{i 3}=w(\mathrm{C})_{\mathrm{CO} 2}=304.04-202.69 r_{d}-202.69 r_{H 2}= \\
288.93-202.69 r_{d}\end{array}$ \\
\hline Carbon provided by coke in a traditional all-coke BF & $w(\mathrm{C})_{1}=214.53+424.73 r_{d}+53.84 r_{H 2}=215.85+424.73 r_{d}$ \\
\hline Carbon provided by coke in a traditional PCI BF & $w(\mathrm{C})_{2}=93.12+424.73 r_{d}+53.84 r_{H 2}=97.14+424.73 r_{d}$ \\
\hline $\begin{array}{c}\text { Carbon provided by coke in a gas-injection BF } \\
\text { Utilization of } \mathrm{CO}=50 \%\end{array}$ & $w(\mathrm{C})_{3}=152.84+424.73 r_{d}+53.84 r_{H 2}=156.86+424.73 r_{d}$ \\
\hline Utilization of $\mathrm{CO}=50 \%$ & $w(C)_{\eta C O=0.5}=577.87-405.39 r_{d}$ \\
\hline
\end{tabular}

$$
\begin{aligned}
& q_{\text {blast }}=\frac{1}{24} \times \frac{0.21}{\frac{f}{0.79-f}+0.21} \times\left(\int_{298}^{\mathrm{T}_{\text {blast }}} c_{\mathrm{P}, \mathrm{O}_{2}} \mathrm{~d} T\right. \\
& \left.+\frac{0.79}{0.21} \int_{298}^{\mathrm{T}_{\text {blast }}} c_{\mathrm{P}, \mathrm{N}_{2}} \mathrm{~d} T\right)
\end{aligned}
$$

where $w(\mathrm{C})_{\text {combustion }}(\mathrm{kg} / \mathrm{tHM})$ represents the carbon burned in the tuyere-raceway region and is obtained after the second heat balance shown in Eq. (8) is solved [36]; $Q_{\text {consumption }}$ represents the heat consumption including the heat spent reducing oxides $\left(Q_{\text {reduction }}\right)$ and the heat carried away by the top gas $\left(Q_{\text {topgas }}\right)$, hot metal $\left(Q_{\text {hotmetal }}\right)$, and slag $\left(Q_{\text {slag }}\right)$. $Q_{\text {reduction }}(\mathrm{kJ} / \mathrm{tHM})$ is calculated by Eq. (9). Ignoring the effect of volatiles in fuels on the top gas, $Q_{\text {topgas }}$ is obtained by Eq. (10). In addition, $Q_{\text {loss }}(\mathrm{kJ} / \mathrm{tHM})$ is assumed to be $10 \%$ of the heat income. $V_{\text {blast }}\left(\mathrm{m}^{3} / \mathrm{tHM}\right)$ represents the volume of the hot blast and is calculated by Eq. (9); $q_{C O}$ denotes the heat released in the oxidation of a kilo of carbon into CO, i.e., 9,800 kJ/kg; $q_{\text {blast }}$ signifies the physical heat obtained from the hot blast by burning one kilo of carbon and is calculated by Eq. (12). In addition, $c_{p, O 2}$ and $c_{p, N 2}$ represent the heat capacities of $\mathrm{O}_{2}$ and $\mathrm{N}_{2}$, respectively, and these values can be obtained from the literature [37]. Finally, $f$ is the rich oxygen rate and is assumed to be $2 \%$ in this paper.

In this paper, three scenarios, the traditional all-coke $\mathrm{BF}$, traditional $\mathrm{PCI} \mathrm{BF}$ and gas-injection $\mathrm{BF}$, are compared on the basis of carbon provided by the coke, i.e., the energy provided by only coke $\left(w(C)_{1}\right)$ in the traditional all-coke $\mathrm{BF}$. When the injected gas conditions, such as the volume and gas composition, are the same as those of the gas produced by pulverized coal in the tuyere region, the essential difference between traditional PCI BF and gas-injection BF is due to the pulverized coal combustion. In terms of the heat consumption, the carbon provided by coke in the traditional PCI BF and gas-injection BF is $w(C)_{2}$ and $w(C)_{3}$, respectively, and can be calculated as follows.

$$
\begin{aligned}
& w(\mathrm{C})_{2}=\frac{\sum_{i} Q_{\text {consumption i }}-Q_{\text {coal }}}{q_{\text {CO }}+q_{\text {blast }}}+w(\mathrm{C})_{\mathrm{d}} \\
& +w(\mathrm{C})_{\mathrm{Si}, \mathrm{Mn}, \mathrm{P}}+w(\mathrm{C})_{\text {carburization }} \\
& w(\mathrm{C})_{3}=\frac{\sum_{i} Q_{\text {consumption i }}-Q_{\text {gas }}}{q_{\mathrm{CO}}+q_{\text {blast }}}+w(\mathrm{C})_{\mathrm{d}} \\
& +w(\mathrm{C})_{\mathrm{Si}, \mathrm{Mn}, \mathrm{P}}+w(\mathrm{C})_{\text {carburization }} \\
& Q_{\text {coal }}=Q_{\text {combustion }}-Q_{\text {coal,blast }}-Q_{\text {coal,decompostion }} \\
& =w(\mathrm{C})_{\text {coal }} \eta_{\text {burn }}-w(\mathrm{C})_{\text {coal }} \eta_{\text {burn }} q_{\text {blast }}-w_{\text {coal }} q_{\text {decompostion }} \\
& Q_{\text {gas }}=\sum_{i} \mathrm{n}_{\mathrm{i} \text { injected }} \int_{298}^{\mathrm{T}_{\text {gas injected }}} c_{\mathrm{P}, \mathrm{n}} \mathrm{d} T \\
& =\frac{w(\mathrm{C})_{\text {CO injected }}}{12} \int_{298}^{\mathrm{T}_{\text {gas injected }}} c_{\mathrm{P}, \mathrm{CO}} \mathrm{d} T \\
& +\frac{w\left(\mathrm{H}_{2}\right)_{\text {injected }}}{2} \int_{298}^{\mathrm{T}_{\text {gas injected }}} c_{\mathrm{P}, \mathrm{H}_{2}} \mathrm{~d} T \\
& +\frac{w\left(\mathrm{~N}_{2}\right)_{\text {injected }}}{28} \int_{298}^{\mathrm{T}_{\text {gas injected }}} c_{\mathrm{P}, \mathrm{N}_{2}} \mathrm{~d} T+\ldots
\end{aligned}
$$

where $Q_{\text {coal }}$ and $Q_{\text {gas }}$ denote the heat provided by the pulverized coal and injected gas and are calculated by Eq. (15) and Eq. (16), respectively. In addition, $w(C)_{c o a l}$ signifies the mass of $C$ in pulverized coal; $\eta_{\text {burn }}$ represents 
the burn rate of pulverized coal, which is assumed to be $90 \%$; $q_{\text {decomposition }}$ is the energy consumption during coal decomposition, which is assumed to be $836 \mathrm{~kJ} / \mathrm{kg} ; w(\mathrm{C})_{\text {coal }}$ is the mass of the pulverized coal, i.e., $167 \mathrm{~kg} / \mathrm{tHM}$; and $\mathrm{n}_{\text {iinjected }}$ represents the molar mass of the injected gas.

To predict the carbon consumption characteristics in a gas-injection $\mathrm{BF}$ and compare them with those of a traditional PCI BF, some gas-injection assumptions are made: (1) The gas volume injected is $700 \mathrm{~m}^{3} / \mathrm{tFe}$, which is equivalent to the gas volume produced by $167 \mathrm{~kg}$ of pulverized coal in a traditional PCI BF. (2) The temperature of the injected gas is $1200^{\circ} \mathrm{C}$, which is the same as that of the hot blast. (3) Using a different oxygen enrichment rate and coal amount, the ratio of $\mathrm{CO}$ and $\mathrm{H}_{2}$ can be changed, but $33.78 \%: 10.07 \% \%$ is used for the comparison with a traditional PCI BF. (4) The excess indirect reduction coefficient is 1 with a large amount of injected reducing gas. (5) The molten iron composition is consistent with that of traditional PCI BF, which is shown in Table 3. (6) The heat consumption items have the same valves as those in traditional PCI BF except for the reducing oxides. (7) $\mathrm{H}_{2}$ participates only in the $\mathrm{FeO}$ reduction reaction in the hightemperature zone.

\section{Results and Discussion}

\subsection{Analysis of the coke-saving potential of the gas-injection BF}

The aforementioned equations and parameters established the relationship between the direct reduction degree $\left(r_{d}\right)$ and the 5 carbon consumption aspects, and the results are shown in Table 4.

By adding $w(\mathrm{C})_{S i, M n, P}$ and $w(\mathrm{C})_{\text {carburization }}$ to $w(\mathrm{C})_{d}$, $w(\mathrm{C})_{i 3}$ and $w(\mathrm{C})_{\eta C O=0.5}$, the relationship between the carbon consumption and $r_{d}$ is obtained. The reasult id shown in Figure 2, which takes into account the chemical consumption and energy penalty.

As shown in Figure 2, the carbon consumption is clearly determined by chemical and heat consumption. For the traditional all-coke BF, the polylines OPQ indicate the carbon consumption with an increase in $r_{d}$. The intersection point $(\mathrm{P})$ shows that the carbon consumption is approximately $426 \mathrm{~kg} / \mathrm{tHM}$ and the corresponding $r_{d}$ is 0.495 . When coke is replaced with pulverized coal as the reducing agent and energy source (PI section), the coke rate of the traditional PCI BF is $357 \mathrm{~kg} / \mathrm{tHM}$, which is consistent with the practical production rate, $355 \mathrm{~kg} / \mathrm{tHM}$. These results indicate that the calculation model is valid.

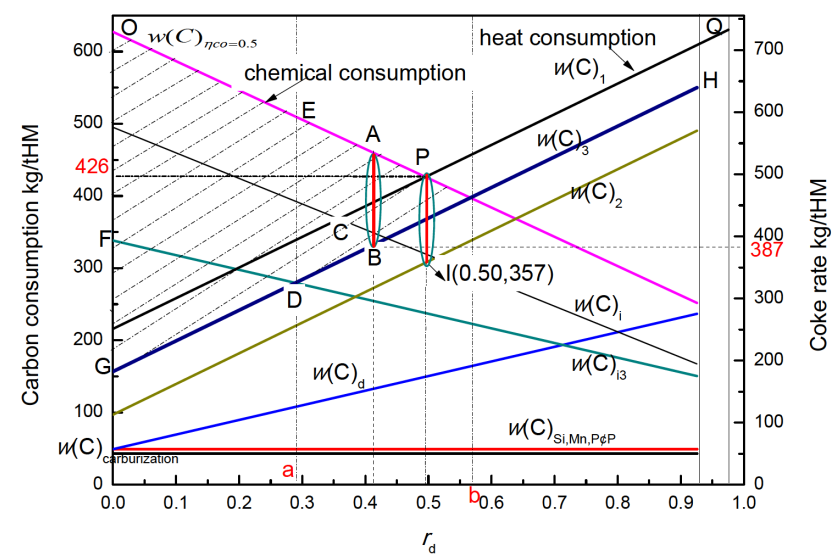

Figure 2: Carbon consumption in different processes

The coke for providing heat in the gas-injection $\mathrm{BF}$ $\left(w(C)_{3}\right)$ is lower than $w(C)_{1}$ and higher than $w(C)_{2}$ due to the lack of coal combustion heat in the tuyere region. When the gas utilization is $50 \%$, the coke ratio of the gasinjection $\mathrm{BF}$ is $387 \mathrm{~kg} / \mathrm{tHM}$, which is higher than that of the traditional PCI BF. Although the carbon-conservation potential in the gas-injection $\mathrm{BF}$ is not exploited under these conditions, increasing the concentration of the injected reducing gases could result in a higher reduction potential with less coke (angular, striped area in Figure 2).

Figure 2 shows that the coke conservation potential of the gas-injection $\mathrm{BF}$ can be analyzed in 3 zones:

1. When $r_{d} \geq \mathrm{b}$, the BF carbon consumption is determined by the heat consumption, and the injected gas functions only as a physical heat carrier. However, injecting a large amount of CO decreases the $\mathrm{CO}$ utilization due to the lower calorific value of CO. In other words, the carbon-conservation potential in the gas-injection BF is not fully exploited when $r_{d}>$ b.

2. When $\mathrm{a}<r_{d} \leq \mathrm{b}$, the BF carbon consumption is mainly decided by indirect reduction. The injected gas provides excess $\mathrm{CO}$ for the indirect reduction ( $A B$ section) and physical heat, which leads to a decrease in the coke rate from point $A$ to point $B$.

3. When $0 \leq r_{d} \leq \mathrm{a}$, the $\mathrm{BF}$ carbon consumption is mainly determined by indirect reduction. The injected gases provide excess $\mathrm{CO}$ and physical heat and are involved in part of the indirect reduction, which can significantly decrease coke consumption. Based on these analyses, the degree of direct reduction should be controlled for $r_{d}<\mathrm{b}$ and $r_{d} \leq \mathrm{a}$ to exploit the coke-saving potential of the gas-injection BF. 
In summary, with abundant injected gas, the coke rate of the gas-injection $\mathrm{BF}$ is determined by the heat consumption (line $\mathrm{GH}$ ), whereas, that of the traditional all-coke and PCI BFs is decided by the indirect reaction and heat consumption (polylines $\mathrm{OPQ}$ ), respectively. In addition, by ignoring the excess coefficient effect, the gas-injection $\mathrm{BF}$ carbon consumption is shown as the polylines FDH when more reducing gas is injected. The minimum carbon consumption and coke rate are located at points D and G, respectively. Therefore, the degree of direct reduction should be not more than the value of point a in terms of the carbonconservation and coke-saving potential.

\subsection{Carbon recycling and $\mathrm{CO}_{2}$ abatement calculations}

The gas-injection $\mathrm{BF}$ process recycles the $\mathrm{CO}_{2}$ in the $\mathrm{BF}$ top gas through a gasifier [32, 38-40], which can save carbon resources and efficiently reduce $\mathrm{CO}_{2}$ emissions.

$$
\begin{aligned}
& \mathrm{C}+1 / 2 \mathrm{O}_{2}=\mathrm{CO}+117,490 \mathrm{~kJ} \\
& \mathrm{C}+\mathrm{CO}_{2}=2 \mathrm{CO}-165,800 \mathrm{~kJ}
\end{aligned}
$$

In the gasifier, the transformation of $\mathrm{CO}_{2} \rightarrow \mathrm{CO}$ produces a direct energy consumption of $165,800 \mathrm{~kJ} / \mathrm{mol}$ and decreases the energy income by $117,490 \mathrm{~kJ} / \mathrm{mol}$ [34] because the gasification reaction consumes carbon, which can no longer combust. The summation of these two parts is the additional energy consumption required in the gasifier to transform one mole of $\mathrm{CO}_{2}$, and this energy must be provided by additional carbon combustion. The carbon consumption in the gasifier is shown in Eq. (19), which is obtained from Eq. (17) and Eq. (18) in terms of the chemical energy conservation [34]. In addition, the total energy of the potential $\mathrm{CO}_{2}$ abatement is calculated by Eq. (20).

$$
\begin{gathered}
\mathrm{x}\left(\mathrm{C}+1 / 2 \mathrm{O}_{2}\right)+\mathrm{C}+\mathrm{CO}_{2}=2 \mathrm{CO}+\mathrm{xCO}+117490 \mathrm{~kJ} \\
\eta_{\mathrm{CO}_{2} \text { utilized }}=\frac{1}{2+x} \times 100 \%
\end{gathered}
$$

Meanwhile, the $\mathrm{CO}$, which is present in an equimolar amount, in the BF top gas can also be recycled. Therefore, the carbon-conservation potential of the injected carbon is expressed as follows.

$$
\eta_{\text {C recycling }}=\frac{1+1}{2+x+1} \times 100 \%
$$

where $\eta_{\text {Cozutilized }}$ and $\eta_{\text {Crecycling }}$ represent the percentages of the reduced $\mathrm{CO}_{2}$ emissions and carbon conserved from the carbon carried by the injected gas respectively, these values are $22.67 \%$ and $36.96 \%$ based on Eq. (20) and Eq. (21), respectively.

The carbon recycling $\left(w(C)_{\text {recycling }}\right)$ and $\mathrm{CO}_{2}$ emission reduction $\left(w(\mathrm{C})_{\text {emissionreduction }}\right)$ amounts can be calculated as follows.

$$
\begin{gathered}
w(\mathrm{C})_{\text {recycling }}=w(\mathrm{C})_{\text {injected }} \times \eta_{\text {C recycling }} \\
=\left(w(\mathrm{C})_{\eta \mathrm{CO}=0.5}-w(\mathrm{C})_{3}\right) \times \eta_{\text {C recycling }} \\
w(\mathrm{C})_{\mathrm{CO}_{2} \text { emissions reduction }}=w(\mathrm{C})_{\text {injected }} \times \eta_{\mathrm{CO}_{2} \text { utilized }} \\
=\left(w(\mathrm{C})_{\eta \mathrm{CO}=0.5}-w(\mathrm{C})_{3}\right) \times \eta_{\mathrm{CO}_{2} \text { utilized }}
\end{gathered}
$$

$$
w(\mathrm{C})_{\text {total }}=w(\mathrm{C})_{\eta \mathrm{CO}=0.5}-w(\mathrm{C})_{\text {recycling }}
$$

For the gas-injection $\mathrm{BF}$, the total carbon consumption $\left(w(C)_{\text {total }}\right)$ is expressed as Eq. (24) when the CO utilization is $50 \%$ and the recycled carbon is excluded. The influence of $r_{d}$ on the potentials of $w(C)_{\text {recycling }}$, $w(C)_{\text {CO2emissionreduction }}$ and $w(C)_{\text {total }}$ is shown in Figure 3(a). In addition to the carbon consumption, the effect on fossil-fuel and process-related $\mathrm{CO}_{2}$ emissions is analyzed for the cost calculation. The total fuel cost, i.e., the sum of the coke and coal costs, is obtained from Eq. (25). Thus, if the excess coefficient effect is ignored $(n=1)$, then the fuel cost is calculated as Eq. (26).

$$
\begin{aligned}
w(\mathrm{C})_{\text {total fuel cost }} & = \begin{cases}\left(\frac{w(\mathrm{C})_{\text {total }}-w(\mathrm{C})_{3}}{\phi(\mathrm{C})_{\text {coal }}}\right) & \\
\times p_{\text {coal }}+\frac{w(\mathrm{C})_{3}}{\phi(\mathrm{C})_{\text {coke }}} \times p_{\text {coke }} & r_{\mathrm{d}} \leq \mathrm{b} \\
\frac{w(\mathrm{C})_{3}}{\phi(\mathrm{C})_{\text {coke }}} \times p_{\text {coke }} & r_{\mathrm{d}} \mathrm{b}\end{cases} \\
w(\mathrm{C})_{\text {fuel cost }} & = \begin{cases}\left(\frac{w(\mathrm{C})_{\text {i }}-w(\mathrm{C})_{3}}{\phi(\mathrm{C})_{\text {coal }}}\right) & \\
\times p_{\text {coal }}+\frac{w(\mathrm{C})_{3}}{\phi(\mathrm{C})_{\text {coke }}} \times p_{\text {coke }} & r_{\mathrm{d}} \leq \mathrm{a} \\
\frac{w(\mathrm{C})_{3}}{\phi(\mathrm{C})_{\text {coke }} \times p_{\text {coke }}} & r_{\mathrm{d}} \mathrm{a}\end{cases}
\end{aligned}
$$

where $\psi(\mathrm{C})_{\text {coal }}$ and $\psi(\mathrm{C})_{\text {coke }}$ denote the fixed carbon contents of coal and coke, $74.37 \%$ and $86.00 \%$, respectively; and $p_{\text {coal }}$ and $p_{\text {coke }}$ represent the price of coal and coke, respectively. The compositions and prices of fuel are dynamic based on the market, region and species, especially for coal, which includes diverse species such as brown coal, bituminous coal, anthracite coal and others. Here, we adopt $2000 \mathrm{RMB} /$ tcoke and $900 \mathrm{RMB} /$ tcoal as moderate values from Tangshan Iron and Steel Enterprises in China for the fuel cost calculations, which includes additional transportation costs. Figure 3 (b) relates the fuel cost and carbon recycling amount to $r_{d}$ to reflect the gas-injection $\mathrm{BF}$ conservation potentials of these aspects.

As shown in Figure 3 (a), the total carbon consumption, including the gasifier, is expressed by the polylines 


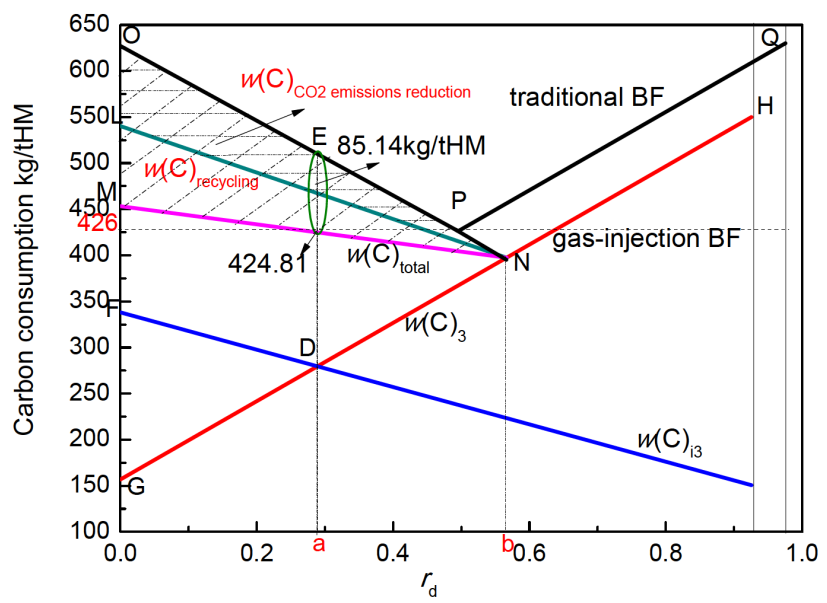

(a) Carbon consumption

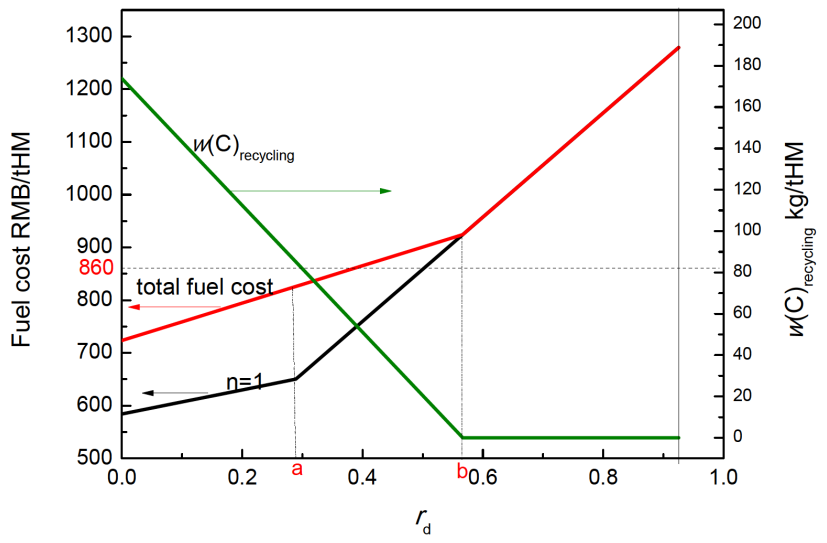

(b) Fuel cost

Figure 3: Effect of $r_{d}$ on carbon recycling and fuel cost

$\mathrm{MNH}$ and is substantially lower than that in a traditional $\mathrm{BF}$ (polylines $\mathrm{OPQ}$ ). In addition, the hatch area represents the carbon recycling potential, and the upper portion is the $\mathrm{CO}_{2}$ abatement potential. In addition, detailed information for $w(\mathrm{C})_{\text {recycling }}$ is shown in Figure $3(\mathrm{~b})$. Although $w(\mathrm{C})_{\text {total }}$ reaches a minimum when $r_{d}=\mathrm{b}, w(\mathrm{C})_{\text {recycling }}$ is 0 , and the gas utilization is lower. Therefore, the direct reduction degree should be lower than $\mathrm{b}$ to exploit the carbonconservation and $\mathrm{CO}_{2}$ emission reduction potential. Ignoring the excess coefficient effect, the carbon consumption minimum should be located at point $\mathrm{D}$ based on the analysis in section 2.3.2. In addition, when $r_{d}=\mathrm{a}, w(\mathrm{C})_{\text {total }}$ is lower than that in a traditional BF ( $426 \mathrm{~kg} / \mathrm{tHM})$, which shows that more than $85 \mathrm{~kg} / \mathrm{tHM}$ of carbon can be recycled without increasing the total carbon consumption. In addition, even in the scenario $r_{d} \leq \mathrm{a}$, the potential for fuel cost savings and carbon recycling can fully compensate for the increasing carbon consumption, as shown in Figure 3 (b). In addition, the total fuel cost is also lower than that in a traditional $\mathrm{BF}$ (860 RMB/tHM). Based on the energy conservation, carbon recycling, $\mathrm{CO}_{2}$ emissions reduction and fuel cost, the direct reduction degree should be maintained in the zone of $r_{d} \leq \mathrm{a}$, which is consistent with the previously presented findings.

\subsection{Optimum operation parameters for energy conservation in a gas-injection BF}

A number of operating parameters, such as the $r_{\mathrm{H} 2}$, rich oxygen rate and gas volume, influence energy conservation. The hydrogen content in coal is much higher than that in coke. The energy consumption is affected by the hydrogen addition and volume of gas injected in the gasinjection BF, as shown in Figure 4 (a) and Figure 4 (b), respectively. Moreover, the rich oxygen rate is a significant factor in inner variable distributions in BFs, such as the temperature, gaseous composition and gaseous volume, and thus, this rate should also be considered in this calculation (Figure 4 (c)).

Figure 4 (a) shows that in contrast to other carbon consumption mechanisms, $w(\mathrm{C})_{\eta C O=0.5}$ and $w(\mathrm{C})_{i 3}$ sharply decrease with increasing in $r_{\mathrm{H} 2}$ (hydrogen addition), which reveals that the energy consumption will decrease with a $\mathrm{H}_{2}$ addition in the gas-injection BF. In addition, the amount of released carbon oxides is also reduced by saving energy. As shown in Figure 4(b), compared with the other carbon consumption mechanisms, $w(C)_{3}$ decreases with an increase in the injected gas volume. With same amount of $w(\mathrm{C})_{\text {burn }}$ in the tuyere region, the physical heat carried by a hot blast will reduce with higher rich oxygen rate, which results in more carbon being needed to provide energy $\left(w(C)_{3}\right)$, as shown in Figure 4 (c). In addition, based on the results obtained from the thermodynamic calculations and kinetics experiments on ore reduction with $\mathrm{H}_{2}$ and $\mathrm{CO}$ additions [41], the maximum reducing gas content should be $10 \% \mathrm{H}_{2}+50 \% \mathrm{CO}$ to ensure a higher gas utilization and reduction rate in the gas-injection BF. The relationship between the BF bosh gas conditions and lower part of the operation parameters was established based on the balance of carbon and oxygen [32]. To summarize aforementioned investigation, a roadmap of the calculation model is shown as Figure 5.

With the same bosh gas volume and 10\% $\mathrm{H}_{2}+50 \% \mathrm{CO}$ in the belly as in a traditional PCI BF, the effect of the injected gas volume on the coke rate is shown in Figure 6, which fully considers the influence of the injected gas conditions (volume, composition and temperature) and the oxygen enrichment rate in the tuyere region. 


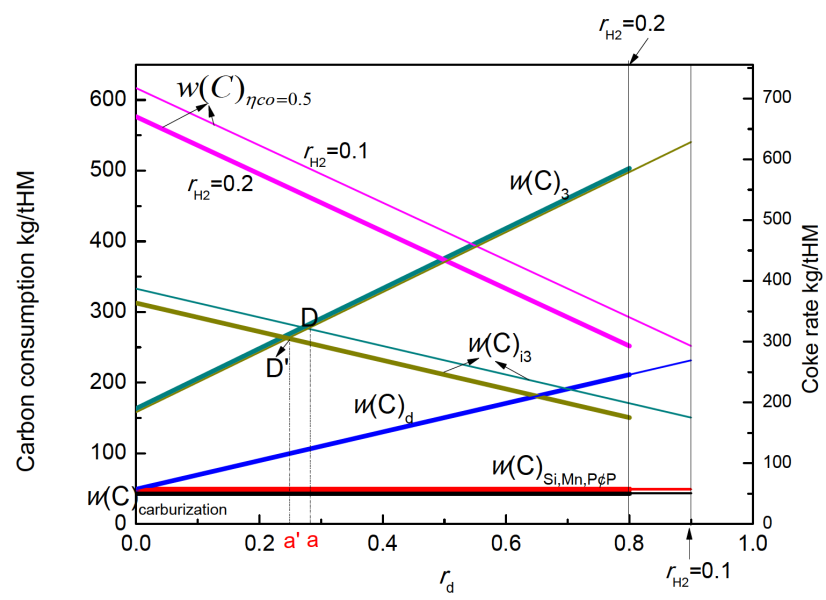

(a) Effect of the hydrogen addition

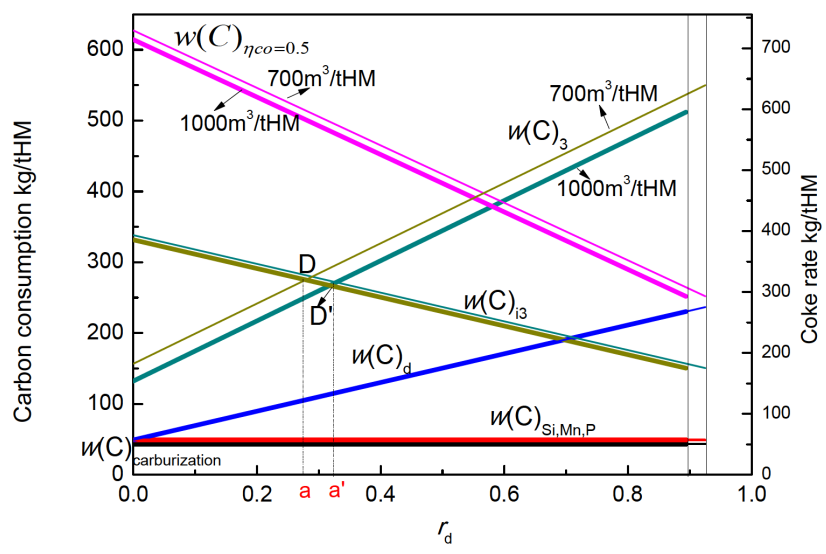

(b) Effect of the injected gas volume

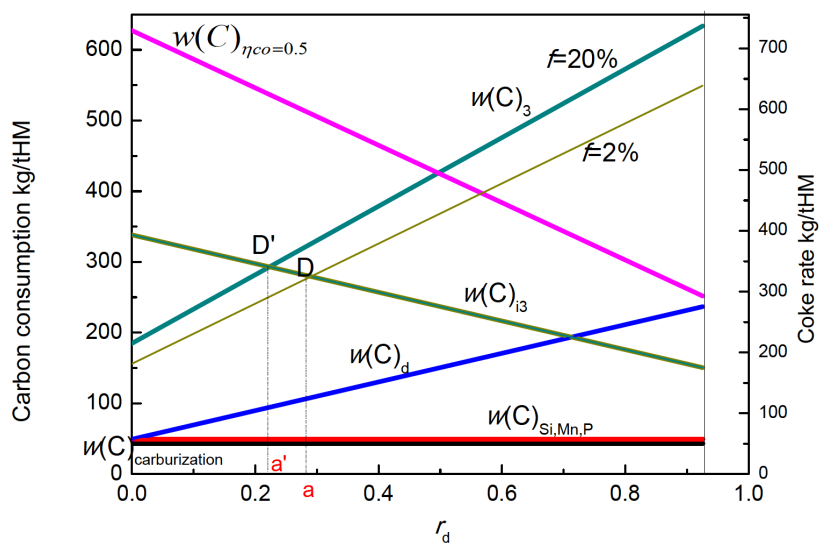

(c) Effect of the rich oxygen rate

Figure 4: Effect of operation parameters on energy consumption in the gas-injection $\mathrm{BF}$

As shown in Figure 6, with an increase in the injected gas volume, the coke rate first decreases before increasing and the rate achieves a minimum with $775 \mathrm{Nm}^{3} / \mathrm{tHM}$ of injected gas. To guarantee a sufficient heat and reasonable gas volume in the BF bosh, the rich oxygen rate should cor-

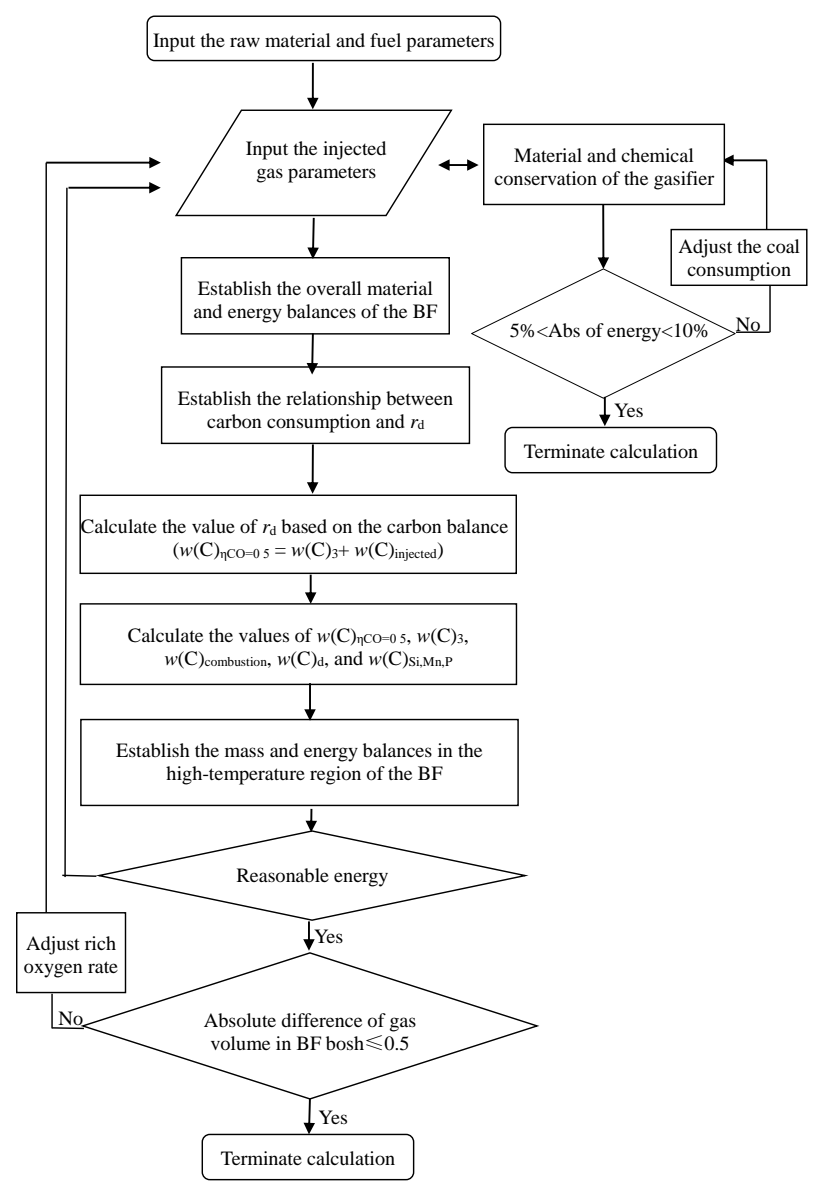

Figure 5: Roadmap of the calculation model for the gas-injection BF

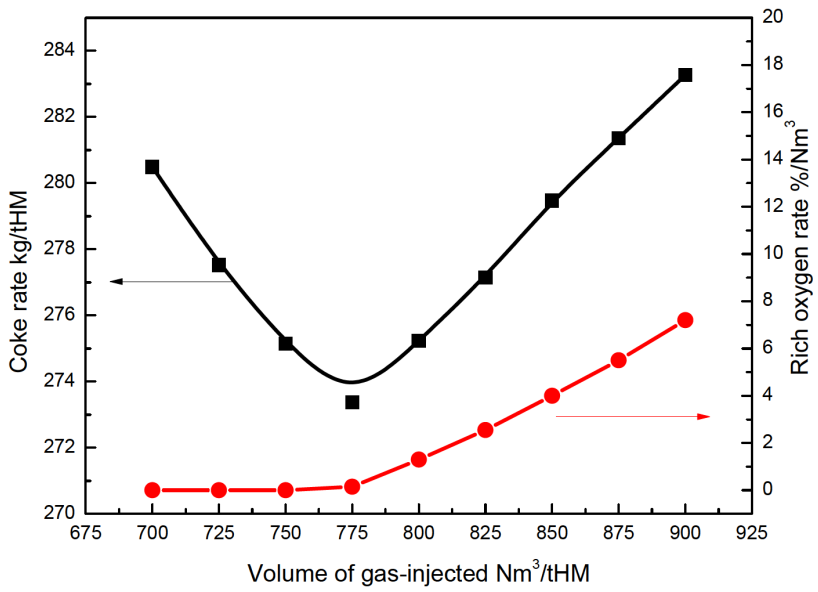

Figure 6: Effect of the injected gas volume on the coke rate in the gas-injection $\mathrm{BF}$

respondingly increase, which will result in a higher coke rate with more than $775 \mathrm{Nm}^{3} / \mathrm{tHM}$ of injected gas. In addition, the optimum parameters of a lower operation schedule are shown in Table 5, and the specific energy conservation information is shown in Figure 7. 
Table 5: Optimum parameters of a lower operation schedule in the gas-injection BF

\begin{tabular}{cccccc}
\hline & \multicolumn{2}{c}{ Injected gas conditions } & \multicolumn{2}{c}{ Hot blast conditions } & Rich \\
$\begin{array}{c}\text { Temperature / } \\
\text { Volume / }\end{array}$ & $\begin{array}{c}\text { Composition / } \\
\text { C }\end{array}$ & $\begin{array}{c}\text { Temperature / } \\
\mathrm{Nm}^{3} / \mathrm{tHM}\end{array}$ & $\begin{array}{c}\text { Volume / } \\
\text { oxygen }\end{array}$ & $\begin{array}{c}{ }^{\circ} \mathrm{C} \\
\text { rate } / \%\end{array}$ \\
\hline 1200 & 775 & $65.63 \% \mathrm{CO}+20.08 \% \mathrm{H}_{2} / \mathrm{tHM}$ & 1200 & 635.72 & 0.15 \\
\hline
\end{tabular}

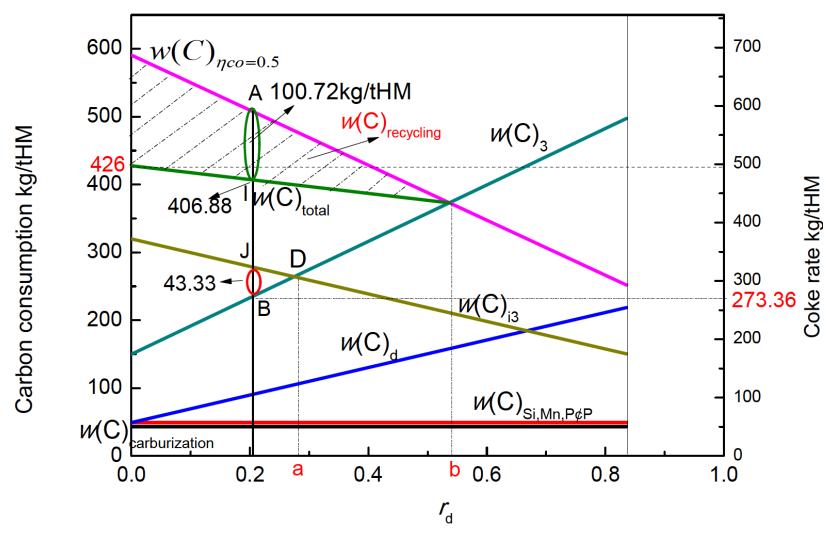

(a) Carbon consumption

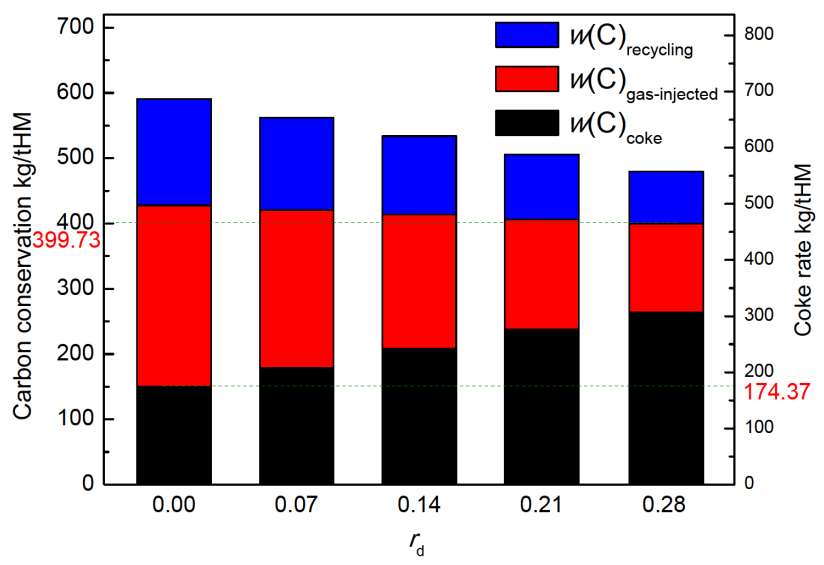

(b) energy conservation with $r_{d} \leq \mathrm{a}$

Figure 7: Energy conservation with $775 \mathrm{Nm}^{3} / \mathrm{tHM}$ of injected gas

Figure $7(\mathrm{a})$ clearly shows that the total carbon consumption is lower than that in traditional PCI BF (426 $\mathrm{kg} / \mathrm{tHM}$ ) when $r_{d} \leq \mathrm{b}$, which indicates the stongt potential for carbon conservation and $\mathrm{CO}_{2}$ abatement in the gasinjection $\mathrm{BF}$. With a CO utilization of $50 \%$ and optimum operation parameters in the tuyere region (Table 5), the coke rate is $273.36 \mathrm{~kg} / \mathrm{tHM}$, which is far lower than that of traditional BF, i.e., $355 \mathrm{~kg} / \mathrm{tHM}$. Approximately $100.72 \mathrm{~kg} / \mathrm{tHM}$ of carbon (AI section) can been recycled and $50.36 \mathrm{~kg} / \mathrm{tHM}$ $\left(94.00 \mathrm{Nm}^{3} / \mathrm{tHM}\right)$ of $\mathrm{CO}_{2}$ can been directly abated; additionally, $43.33 \mathrm{~kg} / \mathrm{tHM}$ of carbon (JB section) in the injected gas (IB section) will take part in indirect reduction, replacing coke. Furthermore, conditions with $r_{d} \leq \mathrm{a}(\mathrm{a}=0.2748)$ have greater energy-conservation and coke-saving potential, as shown in Figure 7(b). In contrast to increasing the coke, the total carbon consumption gradually decreases with the addition of $r_{d}$. For $r_{d} \leq \mathrm{a}$, the minimum values of the coke rate and total carbon consumption are 174.37 $\mathrm{kg} / \mathrm{tHM}$ and $399.73 \mathrm{~kg} / \mathrm{tHM}$, respectively, and these values are due to improving the gas utilization and adjusting the composition of the injected gas. In addition, one advanced and mature coal gasification process, a shell gasifier [4246], can be used to meet the syngas requirements for $\mathrm{BF}$ injection, which ensures the energy conservation and $\mathrm{CO}_{2}$ abatement performances of the gas-injection BF.

On the basis of the aforementioned discussion, the gas-injection $\mathrm{BF}$ clearly has greater coke-saving potential under the optimum operation parameters based on theoretical calculation. These results provide a direction for the reduction of $\mathrm{BF}$ carbon consumption in practice. In $\mathrm{BF}$ operations, operating parameters can be adjusted to approach the optimal state of the theoretical calculation.

\section{Conclusions}

1. Compared with traditional all-coke and PCI BFs, the gas-injection $\mathrm{BF}$ has greater coke-saving potential with adjustment of the injection parameters, although its energy consumption is higher than that of the traditional PCI BF under equivalent conditions. In addition, with abundant injected gas, the coke consumption in the gas-injection BF will be determined by the heat consumption instead of both the chemical and heat consumption.

2. Top gas recycling can provide $36.96 \%$ of the carbon in the injected gas in the gas-injection BF. Based on a comprehensive consideration of energy conservation, carbon recycling, $\mathrm{CO}_{2}$ abatement and fuel cost, the degree of direct reduction should not be greater than a (the value of ' $a$ ' is approximately 0.3).

3. Based on the calculation results, the proper injection parameters, such as $775 \mathrm{Nm}^{3} / \mathrm{tHM}$ of injected gas, $635.72 \mathrm{Nm}^{3} / \mathrm{tHM}$ of blast, $0.15 \%$ rich oxygen rate and a $1200^{\circ} \mathrm{C}$ injection temperature are ob- 
tained. These parameters can reduce the coke rate to $273.36 \mathrm{~kg} / \mathrm{tHM}$ and total carbon consumption to $406.88 \mathrm{~kg} / \mathrm{tHM}$ and increase the carbon recycling to $100.72 \mathrm{~kg} / \mathrm{tHM}$ and $\mathrm{CO}_{2}$ abatement to 94.00 $\mathrm{Nm}^{3} / \mathrm{tHM}$. These results reflect the strong potential for carbon recycling and $\mathrm{CO}_{2}$ abatement in the gasinjection BF.

4. The findings of theoretical calculation a direction for the reduction of $\mathrm{BF}$ carbon consumption in practice. In $\mathrm{BF}$ operations, operating parameters can be adjusted to approach the optimal state of the theoretical calculation.

Acknowledgement: This work was performed in a key laboratory for advanced metallurgy technology of North China University of Science and Technology. Thanks are given to the supports form the key Program of National Nature Science Foundation of China (U1360205), North China University of Science and Technology Distinguished Youth Scholars Fund (JP201508) and Science and Technology Project of Tangshan (19150223E).

\section{References}

[1] World Steel Association, https://www.worldsteel.org/zh/mediacentre/press-releases/2015/the-steel-industry-calls-for-a-rei nforced-partnership.html. July 29, 2015, Brussels, Belgium, 2015.

[2] Xu, K. D. Low carbon economy and Iron and Steel Industry. Iron \& Steel, Vol. 45, 2010, pp. 1-12.

[3] da Rocha, E. P., V. S. Guiherme, J. A. de Castro, Y. Sazaki, and J. Yagi. Analysis of synthetic natural gas injection into charcoal blast furnace. Journal of Materials Research and Technology, Vol. 2, 2013, pp. 255-262.

[4] Abdel Halim, K. S. Theoretical approach to change blast furnace regime withnatural gas injection. Journal of Iron and Steel Research International, Vol. 20, No. 9, 2013, pp. 40-46.

[5] Steer, J. M., R. Marsh, M. Greenslade, and A. Robinson. Opportunities to improve the utilisation of granulated coals for blast furnace injection. Fuel, Vol. 151, 2015, pp. 40-49.

[6] Du, S. W., C. P. Yeh, W. S. Chen, C. H. Tsai, and J. A. Lucas. Burning characteristics of pulverized coal within blast furnace raceway at various injection operations and ways of oxygen enrichment. Fuel, Vol. 143, 2015, pp. 98-106.

[7] Trinkel, V., N. Kieberger, T. Bürgler, H. Rechberger, and J. Fellner. Influence of waste plastic utilisation in blast furnace on heavy metal emissions. Journal of Cleaner Production, Vol. 94, 2015, pp. 312-320.

[8] Wanga, C., M. Larsson, J. Lövgren, L. Nilsson, P. Mellin, W. Yang, et al. Injection of solid biomass products into the blast furnace and its potential effects on an integrated steel plant. Energy Procedia, Vol. 61, 2014, pp. 2184-2187.

[9] Chen, W. H., C. L. Hsu, and S. W. Du. Thermodynamic analysis of the partial oxidation of coke oven gas for indirect reduction of iron oxides in a blast furnace. Energy, Vol. 86, 2015, pp. 758-771.

[10] Chen, W. H., M. R. Lin, A. B. Yu, S. W. Du, and T. S. Leu. Hydrogen production from steam reforming of coke oven gas and its utility for indirect reduction of iron oxides in blast furnace. International Journal of Hydrogen Energy, Vol. 37, No. 16, 2012, pp. 1174811758.

[11] Ghanbari, H., F. Pettersson, and H. Saxén. Sustainable development of primary steelmaking under novel blast furnace operation and injection of different reducing agents. Chemical Engineering Science, Vol. 129, 2015, pp. 208-222.

[12] Jin, P., Z. Jiang, C. Bao, S. Hao, and X. Zhang. The energy consumption and carbon emission of the integrated steel mill with oxygen blast furnace. Resources Conservation and Recycling, Vol. 3062, 2015, pp. 1-3.

[13] Danloy, G., A. Berthelemot, M. Grant, J. Borlee, D. Sert, J. van der Stel, et al. ULCOS - Pilot testing of the Low- $\mathrm{CO}_{2}$ Blast Furnace process at the experimental BF in Luleå. Revue de Métallurgie, Vol. 106, No. 1, 2009, pp. 1-8.

[14] Yeh, C. P., S. W. Du, C. H. Tsai, and R. J. Yang. Numerical analysis of flow and combustion behavior in tuyere and raceway of blast furnace fueled with pulverized coal and recycled top gas. Energy, Vol. 42, No. 1, 2012, pp. 233-240.

[15] Tsupari, E., J. Kärki, A. Arasto, J. Lilja, K. Kinnunen, and M. Sihvonen. Oxygen blast furnace with $\mathrm{CO} 2$ capture and storage at an integrated steel mill - Part II: Economic feasibility in comparison with conventional blast furnace highlighting sensitivities. International Journal of Greenhouse Gas Control, Vol. 32, 2015, pp. 189-196.

[16] Arasto, A., E. Tsupari, J. Kärki, J. Liljia, and M. Sihvonen. Oxygen blast furnace with $\mathrm{CO} 2$ capture and storage at an integrated steel mill-Part I: Technical concept analysis. International Journal of Greenhouse Gas Control, Vol. 30, 2014, pp. 140-147.

[17] Hamid, G., P. Frank, and S. Henrik. Optimal operation strategy and gas utilization in a future integrated steel plant. Chemical Engineering Research and Design, Vol. 102, 2015, pp. 322-336.

[18] Hooeya, L., A. Tobiesenb, J. Johns, and S. Santos.Technoeconomic study of an integrated steelworks equipped with oxygen blast furnace and $\mathrm{CO}_{2}$ capture. Energy Procedia, Vol. 37, 2013, pp. 7139-7151.

[19] Shao, J. G., J. L. Zhang, G. W. Wang, Y. T. Tang, and H. B. Zuo. Theoretical analysis of oxygen-blast furnace iron-making process. Energy for Metallurgical Industry, Vol. 32, 2013, pp. 22-28.

[20] Lan, R. Z., J. S. Wang, Y. H. Han, X. F. She, L. T. Wang, and Q. G. Xue. Reduction Behavior of Sinter Based on Top Gas Recycling-Oxygen Blast Furnace. Journal of Iron and Steel Research International, Vol. 19, No. 9, 2012, pp. 13-19.

[21] Schott, R.State-of-the-Art PCI technology for blast furnace ensured by continuous technological and economical improvement. Iron Steel Technology, Vol. 3, 2013, pp. 63-75.

[22] Luengen, H., M. Peters, and P. Schmöle. Ironmaking in Western Europe. AIST Iron Steel Technology, Vol. 9, 2012, pp. 63-76.

[23] Qie, Y. N., Q. Lyu, J. P. Li, C. C. Lan, and X. J. Liu. Effect of Hydrogen Addition on Reduction Kinetics of Iron Oxides in Gas-injection BF. ISIJ International, Vol. 57, No. 3, 2017, pp. 404-412.

[24] Qie, Y. N., Q. Lyu, X. J. Liu. J.P. Li, C.C. Lan, S.H. Zhang et al.. Hydrogen addition on softening and melting reduction behavior of ferrous burden in gas-injection blast furnace. Metallurgical and Materials Transactions B, Vol. 49, 2018, pp. 2622-2632.

[25] Lyu, Q., F. M. Li, and X. B. Li. Influence of Gas-Injection from Tuyeres of Reduction and Transformation of Solid Charge in Blast 
Furnace. Iron \& Steel, Vol. 43, 2008, pp. 17-21.

[26] Li, F. M., Q. Lyu, and X. B. Li. Influence of Gas-Injection from Tuyeres on Slag Formation in Blast Furnace. Iron \& Steel, Vol. 42, 2007, pp. 12-15.

[27] Guo, H., F. M. Li, and Q. Lyu. Heat Balance of Blast Furnace Operating Enriched Oxygen and Coal Gas-injection from Tuyeres. Journal of Hebei Institute of Technology, Vol. 29, 2007, pp. 27-31.

[28] Li, Y., and L. Zhu. Cost of energy saving and $\mathrm{CO} 2$ emissions reduction in China's iron and steel sector. Applied Energy, Vol.130, 2014, pp. 603-616.

[29] Brunke, J. C., and M. Blesl. A plant-specific bottom-up approach for assessing the cost-effective energy conservation potential and its ability to compensate rising energy-related costs in the German iron and steel industry. Energy Policy, Vol. 67, 2014, pp. 431-446.

[30] Hasanbeigi, A., W. Morrow, J. Sathaye, E. Masanet, and T. F. Xu. A bottom-up model to estimate the energy efficiency improvement and $\mathrm{CO} 2$ emission reduction potentials in the Chinese iron and steel industry. Energy, Vol. 50, 2013, pp. 315-325.

[31] Moya, J. A., N. Pardo, and A. Mercier. The potential for improvements in energy efficiency and $\mathrm{CO} 2$ emissions in the EU27 cement industry and the relationship with the capital budgeting decision criteria. Journal of Cleaner Production, Vol. 19, No. 11, 2011, pp. 1207-1215.

[32] Ren, G. Y. Ironmaking. Vol. 1. Metallurgical Industry Press, Beijing, China, 2008.

[33] Wany, X. L. and C. L. Qi, Proceedings of Ironmaking Technology Conference, Chinese Society for Metals, May 13-15, 2014, Zhengzhou, China, 2014, pp. 69-77.

[34] Ironmaking section of Northeast institute of Technology, Blast Furnace Ironmaking, Vol. II. Metallurgical Industry Press, Beijing, 1978.

[35] Wany, X. L.Study on issue on achievement of low Cost and low carbon Ironmaking by BF in China. An Gang Technology, Vol. 3, 2014, pp. 1-7.

[36] He, Y. D. Ironmaking. Vol. 1. Metallurgical Industry Press, Beijing, China, 1980
[37] Liang, Y. J., and Y. C. Che. Handbook of inorganic thermodynamic data. Northeastern University Press, Shenyang, 1993.

[38] Zhu, L., F. Wang, and Z. Zhang. Thermodynamic evaluation of a conceptual process for coal gasification coupled with chemical looping air separation. Chemical Engineering Progress, Vol. 106, 2016, pp. 33-41.

[39] Prabu, V. Integration of in-situ CO2-oxy coal gasification with advanced power generating systems performing in a chemical looping approach of clean combustion. Applied Energy, Vol. 140, 2015, pp. 1-13.

[40] Kuo, P. C., and W. Wu. Thermodynamic analysis of a combined heat and power system with CO 2 utilization based on cogasification of biomass and coal. Chemical Engineering Science, Vol. 142, 2016, pp. 201-214.

[41] Lyu, Q., Y. N. Qie, X. J. Liu, C. C. Lan, J. P. Li, and S. Liu. Effect of hydrogen addition on reduction behavior of iron oxides in gasinjection blast furnace. Thermochimica Acta, Vol. 648, 2017, pp. 79-90.

[42] Majoumerd, M. M., H. Raas, S. De, and M. Assadi. Estimation of performance variation of future generation IGCC with coal quality and gasification process-Simulation results of $\mathrm{EU} \mathrm{H}_{2}$ IGCC project. Applied Energy, Vol. 113, 2014, pp. 452-462.

[43] Baker, D. C. Projected emissions of hazardous air pollutants from a Shell coal gasification process-combined-cycle power plant. Fuel, Vol. 73, No. 7, 1994, pp. 1082-1086.

[44] Gao, J. Z. Application and development of coal gasification technologies. Clean Coal Technology, Vol. 19, No.1, 2013, pp. 65-71.

[45] Lu, Z. T. Evaluation of Revamping Domestic Large and Medium Ammonia Plants with Shell Pressurized Pulverized Coal Gasification Technology (Part I). Journal of the Chemical Fertilizer Industry, Vol. 28, No. 5, 2001, pp. 3-9.

[46] Promes, E. J. O., T. Woudstra, L. Schoenmakers, V. Oldenbroek, A. T. Thallam, and P. V. Aravind. Thermodynamic evaluation and experimental validation of 253 MW Integrated Coal Gasification Combined Cycle power plant in Buggenum, Netherlands. Applied Energy, Vol. 155, 2015, pp. 181-194. 